\title{
The Heterogeneity of the Socio-Educative Mediation in the Intervention with Debilitated Families: Cases in Study
}

\author{
Laura Magalhães \\ (laura88@sapo.pt) \\ University of Minho - Braga - Portugal
}

Doi:10.5901/mjss.2013.v4n11p167

\begin{abstract}
Mediation, a relatively new field in Portugal, has been contributing innovatively to professional practices, becoming increasingly attractive in various contexts of action. Taking into account the various fields of work, it is important to consider that mediation might be beneficial in collaborating the processes of promotion and protection of the families of children at social risk. Here, the mediation devices become a collaborative resource to be used with these families. The present work has been developed for nine months, as an integral part of the practical training curriculum of the Masters in Education programme, with specialization in Educational Mediation and Supervision of Professional Training. This practical training was developed at The Commission of Protection of Children and Youth, in a rural area in the North of Portugal. The methodology used is qualitative, through the development of a research-action, where the case study was the privileged method. Our aim is to present the several themes used with some of the families in the field of mediation. This form of intervention and monitoring is not commonly practiced in this organization. However, it is possible to motivate a successful transformation in these families. Mediation in these debilitated conditions assumes the function of stimulating the opportunity of creating more stable family environments, contributing to their successful phycho-social development. The success of the process is attributed to the families that participated in the mediation, with the goal that everyone emerges a winner.
\end{abstract}

Keywords: Socio-educative mediation, debilitated families

\section{Introduction}

The present work of investigation-intervention has been developed between October 2010 and June 2011, as an integral part of the practical training curriculum of the $2^{0}$ year Masters in Education programme, with specialization in Educational Mediation and Supervision of Professional Training.

More and more often we realize the prominence of the diversity of contexts and modes of intervention, through a mediation process. They come from the variety of professionals and references that these include to develop their mediation practices.

In this work we pay special attention to socio-educational mediation, particularly social mediation. Social mediation, according to Luison and Valastro (2004:3) is characterized in different ways in different countries. It is described as "a method of resolution and alternative management of conflicts, a method of social regulation and a method of a peaceful recomposition of human relations." It also comes also associated with interdisciplinary contexts.

Taking into account the range of contexts where mediation can bring benefits, it was our purpose with this research to highlight the importance that mediation can have in the cooperation of a process of promotion and protection of children and / or youth considered at social risk. For this reason we have developed a social mediation process with special focus on I debilitated familiar contexts.

The families included in this work were signalized in a Commission of Children and Young People Protection, due to several problems. To the people that participated and contributed in the process of this nature, was given the opportunity to modify their home environment, making it more stable and enjoyable. Therefore we believe that we further contributed in a fruitful way for a better psychosocial development of their families. Otherwise, these families wouldn't be able to change that behaviors that were putting them at risk. Through this project we developed a form of intervention and of monitoring the signalized families, and we should mention that this isn't a common practice in the Commissions of Minors Protection, but it can create a successful transformation. 


\section{Context of study}

A Commission of Children and Youth Protection is a social network that focuses its practices for the protection of children and youth. Whenever parents, legal representative or the person who has the custody of that child or youth puts at risk the full bio-psycho-social development of the child, particularly regarding his health, education, training and / or safety, or even when the danger in question comes from the act or omission of a third person or of the child and / or young, it is legitimate to place an intervention in order to promote and protect the rights of this child that are in danger. According to the Art. 1 and 2, Art. ${ }^{0} 12$ of Law no. 147/99, of Portugal, the protection Commissions are:

"Non-judicial official institutions with functional autonomy, that aim to promote the children and young people rights and to prevent or to put an end to situations that may affect their safety, health, training, education and integral development (...) exercise their powers according to the law and should deliberate in a impartial and independent way. "

Please note that we considered that a child or young person is in danger when he is a victim of some kind of abuse, either physical, psychological and / or sexual; when he is a victim of some kind of negligence and / or when he arrogates behaviors which can seriously undermine his development, health, education, training and safety, without his parents, or the legal representative that has his guard, makes himself available, in a appropriate way, to eliminate these behaviors. The same situation happens when the child is indirectly subject to these same behaviors even if he isn't the protagonist.

All the practices of the Protection of minors Commission in Portugal, are governed by the Law n. 147/99, September 1 - Law on the Children and Youth Protection.

The Protection Commission should be called to act when the entities with the jurisdiction over childhood and youth are proving to be incapable of adequately responding to eliminate the danger that a particular child or young person is on. However, the Commission can only intervene after obtaining the written consent of the child parents, or of the legal representative or of whom has the custody of that concerned child or young person. It is also required that the child or young person, having 12 or more years, provides a written statement of non-opposition. When this fact is not possible, the Commission has no jurisdiction to intervene and the process will be subjected to a judicial intervention. The Commission will also not intervene, when that consent and / or declaration of non-objection will be removed, and for this reason is also going to be subjected to a judicial intervention. It should be emphasized that if the promotion and protection agreement is not fulfilled, a judicial intervention will be conducted.

\section{Theoretical background}

Mediation aims to resolve conflicts between at least two parts, requiring the intervention of a third person, called a mediator. The mediator should be a person not involved in the conflict. The mediator must find ways to help the two sides solving the problems, he has to create conditions that the parties will use to the resolution of the conflicts. This is not imposed by law, but designed by the parts so that both will get benefits. There is no antagonism on winning or losing. So, there can only be mediation when both parts of the conflict are available to be mediated (Torrego, 2003). However, it is not strictly necessary the existence of conflicts regarding the relevance of the mediator intervention. The prevention of the conflicts is also a relevant fact. Mediation covers a wide range of profitable operations contexts. And for this reason, there are many performance models.

Taking into account several readings made on this issue, we realized that the concept of mediation is old. However, this working method is increasingly prominent, particularly in Portugal.

If we pay more and more attention to the voices around us, we see that the word mediation is in "everyone's lips." On the other hand, we also realize that sometimes people exaggerate when they want to connote mediation as all the interventions involving the participation of a third person, in a tumultuous interpersonal interaction. And this will takes us to a certain lightness and even to an inconsistency of the concept and of the mediation process.

There isn't a definition to characterize the pragmatic concept of mediation. Sometimes the initial formation of the mediator can condition the conception of his own explanation. The working field of mediation is not limited only to the intervention in conflicts. Such a situation would lead to a pejorative vision of the conflicts. However, a conflict can and should be seen as an opportunity for personal and social growth (Neves, 2010).

Mediation is not static, it is a process that is being built. Its way of working differs from the other socials interventions, since it is required to the mediated people the explicitly externalization of their will. So, and as argued by Neves (2010:42), "mediation is not exclusively defined by the applied procedures, but indispensably by the relationship 
between the mediator and the parts."

The mediator, often referred as the third part, is the agent that provides the connection of the parts, "is the person, or persons or even institutions, that assumes the connection role or the catalyst role in the mediation processes" (2008:22 Torremorell .) The mediator, in their professional practice, does not act by interests. This is, he does not act on the basis of one of the parts but, as far as possible, he acts as an impartial agent, ensuring the fairness between the opposed parts, not taking advantage of any of them.

Not having a plan to create a pattern of an ideal mediator, it is understood that the mediator, as far as possible, should possess a number of characteristic in his professional profile. Therefore, the mediator should be: fair, empathetic, patient, he has to know how to listen and to talk carefully and with respect with all the involved parts, he should be creative and he has to know how to generate an atmosphere and structure that maximizes the chances of reaching an agreement (Millán and Gómez, 2011:83).

All the protagonists of a mediation process participate in a voluntarily way. This is one of the strongest points indicated in the mediation process. Decisions and / or possible solutions are identified by the mediated people and they are not imposed by anyone, not even indicated by the mediator.

The mediator is not an expert in the resolution of conflicts. He only coordinates the exchange of views between the mediated people, providing them the ability to "confront their point of views and to seek his help in order to find a solution for the dispute between them" (Bonafé-Schmitt, 2009:20), and in this way both parts will win. The empowerment of an entire mediation process is provided to the mediated people. Therefore mediated people are the people "who know more about the causes of their problems and about the ways of overcoming the same" (Freire, 2009:41).

The areas of the mediation intervention are several. As a way to organize them Guillaume Hofnung (2005, cited by Silva and Moreira, 2009:7) outlined two areas: the mediation of differences and the mediation of disputes. The mediation of differences is seen as a creative and refreshing process in the sense that it "seeks to (re) establish ties and interpersonal and social interactions, till then absent or lost, between individuals, groups and communities" (ibidem). While the mediation of disputes, seen as a preventative and reparative process, aims "to prevent and to intervene in the resolution of already existing conflicts. (...) In this sense it can be both preventive and curative "(ibidem).

However, in both cases, the mediation process "is based on a deconstruction-reconstruction logic" (BonaféSchmitt, 2009:24). In the stage of deconstruction the mediator passes the word to each of the parts, each part will expose his point of view, particularly it is given the opportunity to each part to explain their differences. Subsequently, we proceed with the reconstruction phase, the parts, with the mediator's assistance, try to reach an agreement, "a consensual solution based on mutual understanding" (ibidem).

Mediation has acquired a wide variety of forms, "they are all determined by the contents of the communication disturbance that can potentially generate a conflict" (Correia and Caramel, 2010:21), arising, for this reason, as a kind of "mobilizing slogan" (Demazière, 2010:103).

\section{Methodological background}

The methodology used in this project had a qualitative nature and we focused ourselves on the development of a research-action. This research-action assumed that the various parts would adopt an active and participatory posture in the whole process. It is considered as the starting point of a particular a situation and / or problem and not a theory, it is a method oriented for the praxis, leading to the resolution of real situations.

With this project we intended to understand to what extent the mediation, including socio educative mediation, may or may not contribute to the process of promotion and protection of families with children considered at risk. With this work we wanted to understand individual cases. It was not our intention to develop a sample research, but to develop a research that would preserve "the holistic and meaningful characteristics of the events" (Yin, 2005:20). This was also the reason why we resorted to the case study.

Throughout this project that we developed, our aim was to design and implement a Social Mediation device, particularly guided for the familiar contexts, in an individually way, so they could enhance the resources of the Protection Commission and the work of this commission with the families. We also wanted 1) To promote interaction and communication capabilities through 1.1) the development of the sense of responsibility and participation; 1.2) the identification of suitable and unsuitable behaviors; 1.3) the implementation of interaction strategies between different elements of the family, 1.4) the obtainment of adjusted communication habits to the socio affective engagement with the students and, finally, 1.5) the identification of relevant socio affective actions and the engagement with them. Thus, essentially, we wanted to contribute to the improvement of the interactions within the family, through the development of 
communication skills.

The work included a group of five families. The selection of the families group for the Social Mediation was made by the Commission for the Protection of Children and Youth technicians. These selected a sample of families who would be able to immediately start and would be more receptive to this intervention. Later it was explained to them the concept of mediation. To these families were given the option of participating or not in this project, and if they chose not to participate, this decision would not have any kind of reprisals by the Protection of Minors Commission.

Four of the selected families have an open process and are primarily signalized due to the fact that the concerned children are exposed to models of deviant behavior. Another selected family, never had any of promotion and protection process, since the concerned children, until that moment, were not subject to any dangerous situation. However, the intervention mediation would act in a preventive terms in order to avoid the opening of a process. It should be noted that these five families had significant difficulties in communication and interaction within, as well as a low education and poor economic incomes.

\begin{tabular}{|c|c|c|c|c|}
\hline $\begin{array}{c}\text { Particulars } \\
\text { Families }\end{array}$ & Typology & Needs analysis & $\begin{array}{l}\text { No. of sessions pre- } \\
\text { mediation }\end{array}$ & $\begin{array}{l}\text { Actors in the } \\
\text { process }\end{array}$ \\
\hline A & $\begin{array}{l}\text { Female single- } \\
\text { parent }\end{array}$ & \multirow{4}{*}{-Direct observation } & $\begin{array}{lr}\text { Father: } & 2 \\
\text { Mother: } & 3 \\
\text { Couple together: } 0 \\
\text { Children: } \quad 2 \\
\text { Total: } & 7 \\
\end{array}$ & Parents \\
\hline B & $\begin{array}{l}\text { Nuclear with } \\
\text { children }\end{array}$ & & $\begin{array}{lr}\text { Father: } & 1 \\
\text { Mother: } & 2 \\
\text { Couple together: } 1 \\
\text { Cildren: } & 1 \\
\text { Aunt: } & 1 \\
\text { Total: } & 6 \\
\end{array}$ & Parents \\
\hline C & $\begin{array}{l}\text { Nuclear with } \\
\text { children }\end{array}$ & & $\begin{array}{lr}\text { Father: } & 1 \\
\text { Mother: } & 3 \\
\text { Couple together: } 1 \\
\text { Total: } & 5\end{array}$ & Parents \\
\hline$E$ & $\begin{array}{l}\text { Male single- } \\
\text { parent }\end{array}$ & & $\begin{array}{lc}\text { Father: } & 1 \\
\text { Children: } & 2 \\
\text { Paternal grandparents: } & \text { Maternal grandparents: } \\
\text { Aunt: } & 2 \\
\text { Total: } & 8\end{array}$ & $\begin{array}{l}\text { Maternal family } \\
\text { and } \\
\text { Paternal family }\end{array}$ \\
\hline D & $\begin{array}{l}\text { Nuclear with } \\
\text { children }\end{array}$ & $\begin{array}{l}\text {-Documentary analysis } \\
\text {-Direct observation }\end{array}$ & $\begin{array}{lr}\text { Father: } & 0 \\
\text { Mother: } & 0 \\
\text { Couple together: } 0 \\
\text { Total: } & 0\end{array}$ & Parents \\
\hline
\end{tabular}

Table 1: Systematization of the process of intervention with families

\subsection{Presentation of the process}

Family A: This family is characterized as being a single-parent female type, with two children. Parents are divorced, competing for the exercise of parental responsibilities. The children were living with their mother, by mutual agreement between the parents.

In this intervention, we have as intervenients both parents. The main problematic element of this family is due to the fact that children continue to witness some conflicts between their parents.

Regarding the involved feelings, it is possible to verify that the oldest child is troubled and confused with the situation lived between his parents, as well as, with the promiscuous behaviors of the mother. The youngest daughter apparently is a happy child. Based on the measures of the pre-made mediation, it is apprehended that the girl does not have a real perception of the family history, although she understands that her parents are divorced. Regarding the mother, sometimes she feels embarrassed because she wants the father of hers to change some of his behaviors 
towards her, as well as towards their children. Finally, regarding the father, he does not show any significant feeling for all these situations. He shows that he really wishes that the mother will change some of her behaviors related to the economic management of their own money, so, and according to him, she will stop asking him for money to pay her personal expenses.

Taking into account all these references, from our point of view, we realized that it would be better to work the following points, through a process of Social Mediation, which can be changed depending on the will of the parties:

- Clarify the relationship between the parents;

- Ending the discussions of the parents in the presence of children;

We consider therefore that by working these issues through a transformative model, we would be providing better psychosocial development to the children.

Despite of the proposed mediation was accepted by both parents, it was only possible to carry out the steps for the needs evaluating diagnostic, including pre-mediation. Although there have been several efforts accomplished, the successive postponements of the mediation sessions due to professional reasons made by the father, plus the little time for the implementation of the project, lead to the inability to move forward in this case.

Family B: The typology of this family is characterizes as nuclear with a daughter. This family was signalized by a complaint made by the father. He argued that his wife was constantly drunk, preventing her to ensure the household management and organization and preventing her of not having good parenting skills. This situation was continuous causing conflicts between the couple.

After the failure of the implementation of the promotion and protection measure with the parents, the Commission decided to use a support measure from another family (paternal uncles). After that, with the consent of the parents, the child started to be cared by these paternal uncles, maintaining contacts with their parents on weekends and on holiday periods. On one of the weekends when the child was with the parents, the mother and her sister-in-law had a conflict. In this conflict there were reciprocal insults, reportedly due to the fact that the mother had dyed some clothes of his daughter, while she was washing them. After this conflict, the mother and this child's aunt stopped speaking to.

The mother is a lady quite shy and insecure. She recognizes that she is influenced by all the requests made by her daughter, and this situation will not allow the appropriate educational rules to be fulfilled. On the other hand, the father is a man deeply concerned with the welfare of his daughter, a little shy, very collaborative and he has work habits. However, he admits that he does not pay due attention to his wife and he does not adopt the correct behaviors. According to the information given by the child's paternal aunt, the biggest problem of the child is due to the fact that the parents do not impose any rules. Regarding the child she is a shy child. She expresses a strong desire to come back to her parents.

In this intervention, we have as intervenients both parents and the child's paternal aunt. There is a desire shared by all, that the child should return to parental care.

After the 1st mediation session with the couple together, they defined as situations to be worked:

- The strengthening of trust between the couple;

- Improvement of the educational rules established by them.

Some dynamics were made with the couple in order to work these topics, identified by them. After the reassessing of the measure made by the Protection Commission, the commission understood that the couple already had the minimum conditions necessary to take back to their care his daughter. Both parents were more stable as a couple, due to the elimination of their conflicts. This was the reason why the Commission Protection changed the measure of supporting the parents.

We should mentioned that the possibility of mediation was also taken into account as a resource for the resolution of the conflict between the mother and her sister-in-law because this aunt still remains as a stable family rear for these parents. However, this situation has always been rejected by the mother. But from the process of social mediation conceived and executed with the parents, the mother noticed that the dialogue is the core for the resolution of conflicts, and this knowledge made her to overcome the conflict with her sister-in-law. They solve the conflict in an independent way.

Family C: nuclear family typology with three minor children in their charge. The three minors have a protection and promotion measure of support with their parents. There is strong evidence that the father has a drinking problem and smoking habits. And when he was asked by the technicians about his family environment, he said it was okay, especially with his daughters. However, since the pre-mediation session conducted by a mediator, he said that sometimes there are some conflicts between the couple. However he didn't give a big importance to the fact. On the other hand, the mother says that the years of marriage were much suffering and anguish. She mentions that her husband's relationship with his 
daughters is good, although there are daily conflicts between the couple.

Both parents assume the role of intervenients in the mediation process. The essential problem to be worked with this family is the daily conflicts between the couple that come from the non adequate communication adopted by the two of them.

After the 1st mediation session with the couple we realized that due to the peculiar characteristics of the mediated couple it would not be feasible to design a mediation device in a long term.. The degree of motivation was not the same between the parents. The father despite recognizing that mediation can be an asset to his relationship with his wife, does not give much importance to what they have been going over the years, in his marriage relationship. However, on the day of the 1st mediation session with the couple, and after a long discussion between the mediated couple, with the assistance of a mediator, both mediated stated that at this stage, through the aid of the mediation, they will have to work the mutual conflicts that they have daily. The couple think that this is the starting point to clarify and to define their future, regarding their family, because the mother really thought in the possibility of getting a divorce. In the mediation sessions the couple brought for discussion mutual conflicts that were happening on their day-to-day and that were making them worried about.

With the conduct of the mediation sessions, the mediator provided some small progress in the couple's relationship, she was able to put the parents discussing their problems and to alleviate the communication between them.

Family D: This household is consisted of a nuclear family and three young children as well as a relative with some cognitive disabilities. This family was signalized in the Commission due to an anonymous complaint, made by one of the daughters, of full age and who no longer resides with her parents. According to the same, his mother had severe alcohol habits, and she also referred that her younger sisters, who are still living with her parents, are victims of violence. Both parents denied the allegations that triggered the opening of the protection process. The Commission considered that mediation could bring some benefits to this family, they could work the conflicted relationship of the couple, if the couple wanted.

However, during the contact with the family it was clearly the existence of domestic violence. The mediator after observing the situation, and although the Commission considers that mediation could be an asset to this couple, decided not proceed with the proposal of mediation, since it would not be feasible because domestic violence was a practice still present in the life of the couple.

Family E: This family is characterized as being a single parent man family. It consists of two minor children and their father. The mother has passed away a short time ago due to a malignant pathology. Until then these children had never owned a promotion and protection process.

The Commission received a complaint from the mother's family, claiming that since the passing of the mother the minors were prohibited of visiting the maternal family.

Once the Commission knew this family and knew that at that moment there was no danger to these children, the commission considered the mediation process a positive situation to these two families in order to solve this conflict and in order to restore the visits of the minors to the maternal family. This proposal after exposed individually to each family, was accepted.

We should highlight the fact that the father has some cognitive limitations, making it impossible to educate and raise his children, independently. The father had no economic incomes, nor any occupation.

The conflict situation between the families sparked some attitudes and behaviors of revolt on the part of the older child, particularly because they were not allowing him to visit his mother's family. There are indications that some of the behaviors adopted by the rebellious older child, werw planned by the maternal family. The older child is being accompanied by the psychological service of the school that he attends.

Mediation, in this particular case, aims to work with the maternal and paternal family of the minors with the objective of restoring the visits of children to maternal family, emphasizing the way of harmonious dialogue.

After the mediation process the minors start visiting the maternal family again. The children began to visit the maternal family during the weekends and they also start to spend the Saturday night over the maternal family's house. The situation was accompanied by a mediator for some time in order to ascertain the progress of the situation. Both families said that visits always went smoothly as well as the delivery of children.

\section{Process monitoring}

To improve the efficiency of our research, we believe that an evaluation device, namely, a device for regulatory 
assessment could cooperate in the research. We see, therefore, the assessment as "a judgment by which we can talk about a given reality, when we articulate a certain idea or representation of what it should be" (Hadji, 1994:178).

For this reason, we designed a device for regulatory assessment in order to adapt the strategies of social mediation process to the difficulties experienced by each family. The same device gave us the opportunity to understand each case in a individual way, particularly, the ability to understand the various difficulties encountered, throughout the process, of the several intervenients. The different intervenients were the main agents of the mediation and evaluation process. They played "a especially active role, once it is the expression of their aspirations and of their word that it is precisely sought" (Barbier, 1985:247). Therefore, we built and developed throughout this work, the following device that is systematized in the following table.

\begin{tabular}{|l|l|l|l|}
\hline $\begin{array}{l}\text { Technical } \\
\text { variables }\end{array}$ & When evaluating & Who evaluating & What to evaluate \\
\hline \multirow{4}{*}{$\begin{array}{l}\text { The end of each mediation } \\
\text { session }\end{array}$} & * Mediator & $\begin{array}{l}\text { - Self-evaluation } \\
- \text { The process } \\
\text { - Mediated }\end{array}$ \\
\cline { 2 - 4 } & Every two sessions & * Mediated & $\begin{array}{l}\text { - Self-evaluation } \\
- \text { Mediator }\end{array}$ \\
\cline { 2 - 4 } & $\begin{array}{l}\text { At the end of the mediation } \\
\text { process }\end{array}$ & * Mediator & $\begin{array}{l}- \text { Self-evaluation } \\
- \text { The process } \\
- \text { Mediated } \\
- \text { Mediator } \\
- \text { The process }\end{array}$ \\
\cline { 2 - 4 } & $\begin{array}{l}\text { One month after finishing the } \\
\text { mediation process }\end{array}$ & * Mediated & - Results \\
\cline { 2 - 4 } & $\begin{array}{l}\text { throughout the process in order } \\
\text { transverse }\end{array}$ & * Mediator & $\begin{array}{l}\text { - Needs analysis for } \\
\text { mediation }\end{array}$ \\
\hline
\end{tabular}

Table 2: Evaluation device

\section{Some evaluative considerations}

The lack of communication is evident in any conflict. However, the fact that people are willing to dialogue is not a direct condition to solve situations, "rather a< miscommunication >is worse than a <null communication>" (Millán and Gómez, 2011: 29). Mediation can provide real time communication. During the period before the mediation are analyzed all the perceptions about the situation grounds. Subsequently, these reasons may be teased between mediated people with the assistance of the mediator. Konrad Adenauer once said that "we all live under the same sky, but no one has the same horizon." Through mediation, the mediated people can explain to the others what is the "horizon" that they have. In other words, mediation helps creating empathy between the mediated people. Mediated people propose and deliberate about possible solutions to the things that are upsetting and causing problems to them. Through mediation is offered the possibility to "discover the other, and at the same time himself. Working the "l" and "you" in the context of "we" "(Costa, 2009:157). So we can conclude that mediation is a process that is build over time, which can become a "new mode of social regulation" (Bonafé-Schmitt, 2009:16).

After a comprehensive analysis of the families we can realize that mediation can be a fruitful multidisciplinary team of a Protection of minors Commission and also may enrich the work done by it. However, not all the cases can be part of a mediating process. The mediation process requires and demands some characteristics that all the families should have. All the parts should desire to participate in a process of this nature and, in turn, they should give a free and informed consent for the same process. Because, and talking particularly about these families, when mediation was proposed to these families the process was clearly explained to them. After the families were informed that regardless of their choice they would not have any reprisals by the Commission, as well as, if they wished to subsequently abandon the process, could do it also without any kind of reprisals. Each case must be worked in a unique way. In cases of violence, including domestic violence, mediation can't continue. Otherwise mediation will not be feasible, as it happened to the family $D$.

Over the situations discussed above, we could realize that in families B and C we developed a mediation of disputes. The intention of the participation of these families came from the desire to work the conflicts already existing in the familiar contexts, and to prevent their minor descendants to adopt pejorative behaviors, which until then exercised by 
the parents. In these families there was also a plan to develop a transformative mediation. We developed a process focused in the mediated people and in their change. The conflicts between them were an opportunity for them to grow. It was possible to see that mediated people had a honest concern about the welfare of the other part. With these families, during the mediation processes, we worked aspects like self-esteem and emotional stability, trying to reduce the effects of destructive conflict. We also the expressive, communicative and interactive aspects in order to improve the affection between the parents, through the communication and interaction between them. These points were reinforced by the analysis of the social conditions that propitiate the situations, from the research of the factors that catalyze the less healthy expressions. We should remind you that they were two individual processes, which led us to results in different proportions, as has been evidenced.

Adversely, in the family $\mathrm{E}$, we worked a mediation of differences. In this family there was the intention to develop a mediation that attempted the restoration of interpersonal interactions, particularly between the maternal and the paternal family of the concerned children, that were lost with the death of the mother. This process was developed in order to allow the children to grow and live with their two families. This mediation provided the non opening of a promotion and protection process by the Commission. So, due to the circumstances provided by the families it was developed a mediation model with the objective of solving all the situations/conflicts. In this area we focused on the conflict resolution among families.

The work of a Protection of minors Commission requires teamwork. Having into account the complexity of the issues with which the Commission is faced, we believe that these should be treated systemically, this is, we should look to the family as a whole. So, it is possible to "see beyond the child, considering the whole family as the unit of intervention (...) and recognize that the welfare of each family member affects all the others" (Mc William et al, 2003:47).

We believe that for an efficient and above all an effective intervention, the nuclear family should be the core of any device intervention, the decisions for a possible solution for the problems in which they are involved must come from them. So, in this case, a "family-centered approach recognizes that the same size does not fit all the parts. Each family is unique and the services must be individually designed "(Mc William et al, 2003:15)

We consider that a device of social mediation focused on the family and ally to the Commission's intervention, even in a autonomous way, cooperates for the sanity of the family. However, the people who participate in a process of this nature contribute in some ways, to the non reproduction of some behaviors and attitudes by the descendants, particularly during adulthood.

Since attitudes influence behavior, it is necessary to realize the knowledge that they have regarding the situation, trying to figure out what they think and, in turn, trying to understand if they have done something to change the situation. After this study, the mediator may perceive the direction of attitudes, their intensity, and he also has to verify if these are one-dimensional or multidimensional attitudes. He can also tell which was the dominant process used to acquire them.

It is evident that mediation has a certain education character, because the intervenients learn by themselves to resolve a conflict and / or prevent it. It is a process that uses acts of democracy, autonomy and respect for the others. Mediation is away to set action lines that a mediator defines to act on the field. It is a complex process, but at the same time a challenging and rich process because of the results that can be achieved from it.

\section{References}

Barbier, J. M. (1985). A avaliação em Formação. Porto: Edições Afrontamento.

Bonafé-Schmitt, J.-P. (2009). Mediação, conciliação, arbitragem: técnicas ou um novo modelo de regulação social. In A. M. Silva, \& M. A. Moreira (orgs.), Formação e Mediação Sócio-educativa. Perspectivas teóricas e práticas. Porto: Areal Editores, 15-40.

Correia, J. A., \& Caramelo, J. (2010). A construção social e legislativa da mediação: figuras e políticas. In J. Correia, \& A. M. Silva (orgs), Mediação: (D)Os Contextos e (D)Os Actores. Porto: Edições Afrontamento, 13-32.

Costa, E. P. (2009). Novos espaços de intervenção: a mediação de conflitos em contexto escolar. In J. V. Sousa (org.), Mediation and consensos building: the new toolds for empowering citizens in the european union. Coimbra: Mediacom/Minerva, 115-166.

Demazière, D. (2010). A mediação social, um trabalho de terreno. In J. Correia, \& A. M. Silva (orgs.), Medição: (D)Os Contextos e (D)Os Actores. Porto: Edições Afrontamento, 103-117.

Freire, I. (2009). Mediação e formação: em busca de novas profissionalidades e de novos perfis profissionais. In A. M. Silva, \& M. A. Moreira (orgs.), Formação e Mediação Sócio-educativa. Perspectivas teóricas e práticas. Porto: Areal Editores, 41-46.

Hadji, C. (1994). A avaliação, regras do jogo. Das intenções aos instrumentos. Porto: Porto Editora.

Luison, L. \& Valastro, O. (2004). Du processos aux pratiques de médiation. In Esprit critique, vol.06, n. 03.

Mc William, P. J., Winton, P., \& Crais, E. (2003). Estratégias práticas para a intervenção precoce centrada na família. Porto: Porto Editora.

Millán, J., \& Gómez, M. (2011). Conflitos. Como desenvolver capacidades enquanto mediador. Lisboa: Escola Editora. 
Neves, T. (2010). Modelos de mediação social. In J. Correia, \& A. M. Silva (orgs.), Mediação: (D)Os Contextos e (D)Os Actores. Porto: Edições afrontamento, 33-43.

Silva, A. M., \& Moreira, M. A. (2009). Falar e escrever de formação e mediação no contexto actual. In A. M. Silva, \& M. A. Moreira (orgs,), Formação e Mediação Sócioeducativa. Perspectivas teóricas e práticas. Porto: Areal Editores, 6-13.

Torrego, J. (2003). Mediação de conflitos em instituições educativas. Porto: Edições ASA.

Torremorell, M. C. (2008). Cultura de Mediação e Mudança Social. Porto: Porto Editora.

Yin, R. (2005). Estudo de Caso. Planejamento e Métodos. Porto Alegre: Bookman. 